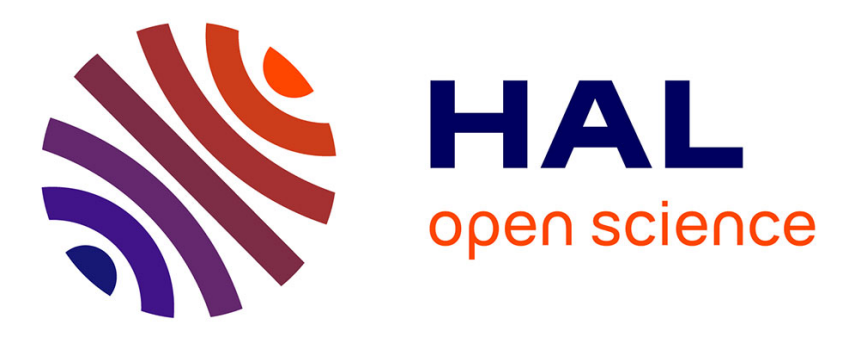

\title{
Epilithic chironomid larvae and water enrichment: is larval distribution explained by epilithon quantity or quality?
}

A. Maasri, Stéphanie Fayolle, Emmanuel Gandouin, Robert Garnier, Evelyne Franquet

\section{To cite this version:}

A. Maasri, Stéphanie Fayolle, Emmanuel Gandouin, Robert Garnier, Evelyne Franquet. Epilithic chironomid larvae and water enrichment: is larval distribution explained by epilithon quantity or quality?. Journal of the North American Benthological Society, 2008, 27 (1), pp.38-51. 10.1899/07013R1.1 . hal-02959131

\section{HAL Id: hal-02959131 \\ https://hal-amu.archives-ouvertes.fr/hal-02959131}

Submitted on 6 Oct 2020

HAL is a multi-disciplinary open access archive for the deposit and dissemination of scientific research documents, whether they are published or not. The documents may come from teaching and research institutions in France or abroad, or from public or private research centers.
L'archive ouverte pluridisciplinaire HAL, est destinée au dépôt et à la diffusion de documents scientifiques de niveau recherche, publiés ou non, émanant des établissements d'enseignement et de recherche français ou étrangers, des laboratoires publics ou privés.

\section{(c)(1) $\$$}

Distributed under a Creative Commons Attribution - NonCommercial| 4.0 International 


\title{
Epilithic chironomid larvae and water enrichment: is larval distribution explained by epilithon quantity or quality?
}

\author{
Alain Maasri ${ }^{1}$ AND Stéphanie Fayolle ${ }^{2}$ \\ Institut Méditerranéen d'Ecologie et de Paléoécologie (CNRS-UMR 6116), Université Paul Cézanne, \\ Aix Marseille III, 13397 Marseille cedex 20, France
}

Emmanuel Gandouin ${ }^{3}$

Institut de Recherche sur la Biologie de l'Insecte (UMR/CNRS 6035), Faculté des Sciences et Techniques, Université François Rabelais, Avenue Monge, Parc Grandmont, 37200 Tours, France

Robert Garnier ${ }^{4}$ AND Evelyne Franquet ${ }^{5}$

Institut Méditerranéen d'Ecologie et de Paléoécologie (CNRS-UMR 6116), Université Paul Cézanne, Aix Marseille III, 13397 Marseille cedex 20, France

\begin{abstract}
The effects of nutrient enrichment of stream water on epilithic chironomid larval assemblages were examined during spring in a Mediterranean catchment. Three reaches that differed in degree of enrichment were selected for comparison. Water chemistry, epilithon biomass (as ash-free dry mass [AFDM]), epilithic algal biomass (as chlorophyll $a$ [chl $a]$ ), algal biovolumes, and algal composition were analyzed to determine their association with density and taxonomic composition of epilithic chironomids. Kendall's $\tau$ coefficient of rank correlations and canonical correlation analysis were used to evaluate correlations between the chironomid and algal assemblages. Significant correlations were found between chironomid larval densities and total algal cell densities and biovolumes. Chironomid larval densities were not significantly correlated with chl $a$ or AFDM. Several contrasting trends were identified in the relationships between chironomid and algal assemblages. Densities of fixed-tube scrapers, such as Eukiefferiella claripennis and Cricotopus bicinctus, were strongly correlated with biovolumes of Rhodophyceae and Diatomophyceae, whereas densities of freeliving scrapers, such as Thienemaniella, were slightly correlated with Chlorophyceae biovolume. Therefore, nutrient enrichment strongly influenced epilithic chironomid assemblage structure through its effects on biovolumes and cell densities of the epilithic algal assemblages.
\end{abstract}

Key words: Chironomidae, Eukiefferiella claripennis, Cricotopus bicinctus, water enrichment, epilithic algae, microhabitat scale study, food availability.

Streams in the Mediterranean region are subject to high organic and nutrient enrichment caused by flourishing tourism activities and associated increases in human population and anthropogenic effects (e.g., sewage treatment and agriculture runoff). Consequently, invertebrate richness in many impacted streams has decreased, whereas densities of less-sensitive taxa, such as chironomids, have tended to increase.

\footnotetext{
${ }^{1}$ E-mail addresses: alain.maasri@univ-cezanne.fr

2 stephanie.fayolle@univ-cezanne.fr

3 emmanuel.gandouin@univ-tours.fr

4 robert.garnier@univ-cezanne.fr

5 evelyne.franquet@univ-cezanne.fr
}

Chironomid assemblages are recognized as reliable water-quality indicators, and they have been widely studied in impacted ecosystems (Ruse and Wilson 1984, Armitage and Blackburn 1985, Wilson 1994, Calle-Martinez and Casas 2006). In addition, their rapid population growth and high densities in enriched streams suggest that chironomid assemblages play a key role, particularly in food webs, in impacted aquatic ecosystems (e.g., Benke 1998). Thus, chironomid larvae are a link in the turnover of organic matter within the stream system. Moreover, chironomid adults affect the food webs of adjacent ecosystems at the catchment scale (e.g., through bat and bird predation). 
Species composition of chironomid assemblages differs qualitatively and quantitatively among microhabitats, and larvae are highly selective in their choice of a site (e.g., Franquet 1999, Vos et al. 2002). Preferences of chironomid larvae for some abiotic factors, such as depth, substratum composition, dissolved $\mathrm{O}_{2}$, and current velocity, are relatively well documented (e.g., Chaloner and Wotton 1996, Rae 2004). The wide spectrum of feeding habits and variations in diet resulting from factors such as larval size, food quality, and sediment composition suggests that chironomid larvae have complex interactions with their food sources (Berg 1995). McLachlan et al. (1978) and Mattingly et al. (1981) found a positive relationship between the growth rate of chironomid larvae and organic matter availability, and Ward and Cummins (1979) demonstrated that growth rates of Paratendipes albimanus are a function of bacterial densities associated with organic matter. Chironomid larvae graze on epiphytic (Drake 1982, Tokeshi 1986, Silver Botts and Cowell 1992) and epilithic algae (Gresens 1995, Goldfinch and Carman 2000), with a variety of herbivory impacts. Silver Botts and Cowell (1992) and Silver Botts (1993) showed that selective grazing of some epiphytic chironomid larvae led to a reduction of the biovolume of algal species preferred as food and increased clumping of the nonpreferred species. Goldfinch and Carman (2000) showed that chironomid feeding rates increased with increasing algal food availability up to a certain food concentration, then they decreased at higher food concentrations because of changes in gut-residence times. These studies suggest that organic matter quantity and quality (detritus, algae, and bacteria) might play a major role in structuring chironomid larval assemblages.

The purpose of our study was to examine in situ the structure of the epilithic chironomid larvae assemblages on stones in riffles of reaches with different degrees of water nutrient enrichment. Our study was done in spring when discharge was relatively high because the low-flow summer conditions typical of small Mediterranean streams lead to a decrease in the area and depth of riffle zones and to discontinuities in the water course (e.g., Bonada et al. 2006). We addressed the following questions: 1) Do epilithic chironomid larvae respond to changes in the epilithon caused by nutrient enrichment of the water column? and 2) If so, what is the relative importance of algal vs nonalgal organic matter to the structure of the epilithic chironomid assemblages in different nutrient conditions? In our study, quality is used to describe the differences in types of food items available for larvae (i.e., total organic matter in the epilithon, epilithic algae, and different algal classes), whereas quantity is the expression of these items in quantitative values (i.e., ash-free dry mass [AFDM], chlorophyll $a$ [chl $a$ ], cell density, and algal biovolume).

\section{Methods}

\section{Study site}

The Arc stream is a coastal Mediterranean stream situated in southeastern France; it rises at $467 \mathrm{~m}$ above sea level, flows for $85 \mathrm{~km}$, and drains a $780-\mathrm{km}^{2}$ catchment. Our study was done in the upper part of this catchment where 2 riffles were selected in each of 3 reaches (6 riffles total). Two of the 3 reaches were on the main course of the stream, and 1 reach was on an adjacent tributary (Fig. 1). All reaches had the similar high \% canopy cover and a low slope. Water depth was $<50 \mathrm{~cm}$ in all reaches, and it was $<12 \mathrm{~cm}$ in the riffles. Mean stream width was $3 \mathrm{~m}$ in the main course reaches and $1 \mathrm{~m}$ in the tributary.

Reaches were chosen on the basis of a pilot project done in 2003 that revealed nutrient enrichment in the upper part of the Arc stream catchment (AM, unpublished data). Reach A (tributary) is characterized by low enrichment. Reach B (main course) is not affected by any point source of organic effluent, but it is affected by diffuse nutrient enrichment from agricultural activities. Reach C (main course) has the highest level of enrichment because of inputs of organic effluent $7.3 \mathrm{~km}$ upstream of the reach (Fig. 1).

Previous collections of invertebrates in the study reaches always were dominated by chironomids. In the riffles, Baetis sp. was the major invertebrate grazer. The predaceous leech Helobdella stagnalis also was present. Densities of these taxa were highest in reach C. Other invertebrates encountered sporadically in the 3 reaches were Asellus sp., Dugesia sp., Caenis sp., Simuliidae, Physa sp., and Ancylus fluviatilis.

\section{Field and laboratory procedures}

Field.-Sampling was done in the spring 2004 on 6 dates (31 March, 8 and 20 April, 6 and 17 May, and 1 June). Dissolved $\mathrm{O}_{2}$ was measured using a dissolved $\mathrm{O}_{2}$ pocket meter with a CellOx 325 probe (WTW, Weilheim, Germany). Water temperature $(\mathrm{T})$ and conductivity (WC) were measured using a LF330 hand-held conductivity meter with a TetraCon ${ }^{\circledR 3} 325$ conductivity cell (WTW). Water samples were collected on each sampling date in the 3 reaches and were analyzed for $\mathrm{NO}_{3}{ }^{-}, \mathrm{NO}_{2}{ }^{-}$, and $\mathrm{NH}_{4}{ }^{+}$with a Technicon II AutoAnalyser (Swords, Dublin, Ireland). Total P (TP), dissolved reactive $\mathrm{P}$ (DRP), and $\mathrm{SO}_{4}{ }^{2-}$ were determined using methods described by Rodier (1984). Current velocity was measured $3 \mathrm{~cm}$ above the bottom 

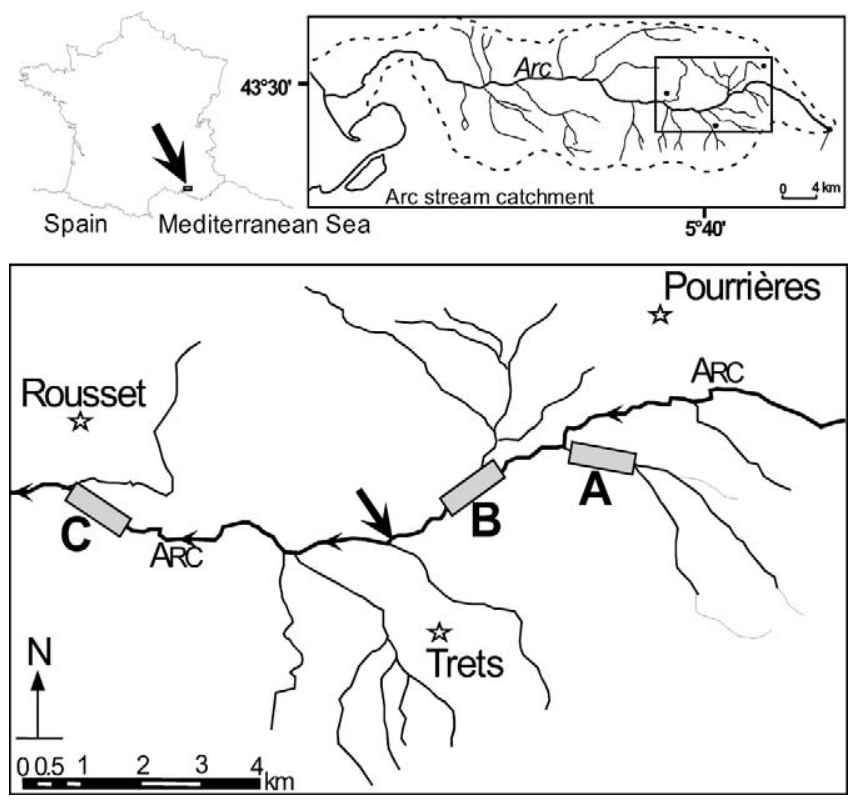

FIG. 1. Arc stream catchment showing the 3 study reaches. Reach $A$ is on the Aubanède tributary; reaches $B$ and $C$ are on the main stream course. The arrow indicates the outflow from the wastewater treatment plant.

at each sampling location with an electromagnetic FloMate 2000 flow meter (Marsh-McBirney, Frederick, Maryland).

On each date at each riffle, 3 stones (pebble and cobble) were picked randomly. The bottom surface of each stone was brushed in the field to eliminate nonepilithic chironomid larvae (e.g., Tanytarsini building tubes attached to the bottom surface of the stones were removed to prevent larvae from moving to the upper surface before processing). Each stone was put in a separate plastic box, and boxes were chilled before being processed at the laboratory. Stones were not returned to the field after processing to ensure that they were not collected twice.

Chironomids.-All chironomid larvae were picked from each stone with forceps under a magnifying glass, and they were preserved in a formalin solution. Larvae were sorted under a dissecting microscope and cleared with a $50 \% \mathrm{KOH}$ for $48 \mathrm{~h}$ at room temperature. Larvae were rinsed in tap water and dehydrated with 95\% ethanol before being mounted between slides in glycerin for identification under a Wild M20 ${ }^{\circledast}$ (Wild, Heerbrugg, Switzerland) binocular microscope (400×, 600×) using keys in Bode (1983), Klink and Moller Pillot (2002), Schmid (1993), and Wiederholm (1983). Some chironomid taxa collected in the study (e.g., Eukiefferiella claripennis and Cricotopus bicinctus) were reared successfully in the laboratory, and exuviae were used to confirm larval determinations (Langton 1991). Chironomid taxa were coded as in Schnell et al. (1999).

Epilithic algae.-After chironomid larvae were removed, epilithon was thoroughly scraped from 3 areas $\left(6 \mathrm{~cm}^{2}, 6 \mathrm{~cm}^{2}\right.$, and $\left.2 \mathrm{~cm}^{2}\right)$ on the surface of each stone with a scalpel. The material from the first $6-\mathrm{cm}^{2}$ area was filtered through a $4.7-\mathrm{cm}$ Whatman GF/C glassfiber filter (Whatman International, Maidstone, UK), dried at $60^{\circ} \mathrm{C}$ to constant mass, weighed, combusted at $500^{\circ} \mathrm{C}$ for $2 \mathrm{~h}$, and reweighed to obtain the epilithon biomass as AFDM. Material from the other $6-\mathrm{cm}^{2}$ area was filtered through a $4.7-\mathrm{cm}$ Whatman GF/C glassfiber filter to determine epilithic algal biomass as chl $a$. Chlorophylls were extracted for $24 \mathrm{~h}$ at $4^{\circ} \mathrm{C}$ in $90 \%$ acetone (Millerioux 1975), and chl a was measured spectrophotometrically (Jeffrey and Humphrey 1975). Material from the $2-\mathrm{cm}^{2}$ area was preserved in $20 \mathrm{~mL}$ of Lugol's iodine solution for taxonomic and biovolume measurements.

A subsample of the algal solution was put in a 10mL Utermöhl counting chamber (Utermöhl 1958) that was then filled with filtered water (1.2- $\mu \mathrm{m}$ pore size). After settling, at least 400 diatom cells and all nondiatom cells were counted in $\geq 1$ diametric bands of the circular settling chamber. When filamentous or colonial algae were encountered, all cells were counted. Identification of diatom and nondiatom algae was made using specific identification keys (Bourrelly 1966, 1968, 1970, Krammer and Lange-Bertalot 1986, $1988,1991 \mathrm{a}, \mathrm{b})$. Counting and identification were done under 400× magnification using an Olympus IX70 inverted microscope equipped with a phase contrast and a calibrated micrometer. Diatom species identification was done from subsamples of the aliquot that were combusted $\left(500^{\circ} \mathrm{C}\right)$ onto coverslips and mounted in NAPHRAX ${ }^{\circledast}$ (Brunel Microscopes Ltd., Chippenham Wilts, UK) for identification of cleared diatom valves at $1000 \times$ magnification. Algal biovolume was estimated from measurements of 10 cells per reach of each taxon that made up $\geq 1 \%$ of the total abundance (31 taxa). Measurements of appropriate cell dimensions and biovolume calculations of cells based on geometric formulae were done using the program BIOVOL (http://www.msu.edu/ kirschte/biovol). Algal taxa were not identified or measured in samples from the first sampling date; consequently, taxonomic composition and cell biovolume data are from only 5 sampling dates.

Stone surface area.-The surface area of each stone was estimated by the foil-wrapping method. Aluminum foil was molded over the upper surface of the pebble to conform closely to its shape, and all overlapping pieces of foil were removed. Aluminum foil was used instead of plastic film to reduce tearing 
and stretching. A regression equation based on the mass-area relationship for the foil $(n=25)$ was used to convert the masses of the foil pebble wrappings to areas. Surface areas were used to calculate chironomid densities.

\section{Data analysis}

Reach-scale survey.-Friedman's test (significance threshold $p=0.05$ ) was used to test for differences in physicochemical variables among reaches (STATISTICA, version 6.0; StatSoft, Tulsa, Oklahoma). One-way analysis of variance (ANOVA; significance threshold $p$ $=0.05$ ) was used to test for differences in water velocity, stone surface area, and the biotic variables on the upper surface of these stones (AFDM, chl $a$, algal cell densities, algal biovolumes) among reaches (STATISTICA).

Microhabitat survey.-Correlation analysis (STATISTICA) was used to test responses of chironomids to algal and nonalgal organic matter per unit surface area. Correlations between larval densities and chl $a$, AFDM, total algal cell density, and total algal biovolume were done using 81 samples ( 5 dates $\times 6$ riffles $\times 3$ stones $=90-9$ samples [missing data]) for which all variables (total epilithon biomass, epilithic algae, and chironomid larvae) were available. Individual chironomid taxa might have interacted differently with biovolumes of each algae class. Therefore, nonparametric Kendall's $\tau$ correlations were used to test correlations between densities of each chironomid taxon (at species and genus levels) and biovolumes of each algal class. Threshold levels of significance for correlations were adjusted for multiple comparisons following Bonferroni's sequential correction (Holm 1979).

Canonical correspondence analysis (CCA; CANOCO for Windows, version 4.5; Microcomputer Power, Ithaca, New York) was used to relate the distribution of chironomid taxa to epilithon quality. CCA is a powerful tool for simplifying complex data sets and allows integrated analysis of both taxa and environmental data because it is a direct gradient analysis. The goal of the CCA was to relate chironomid species distribution to differences in chl $a$, AFDM, and biovolumes of the 4 algal classes in epilithon occurring on the surface of the stones (environmental variables for the CCA). CCA was selected because chironomid species distribution was expected to have a unimodal response to environmental variables (Ali et al. 2002). Chironomid larval density data were $\log _{10}(x+1)$ transformed and rare species were down-weighted. The variability in chironomid species data explained by individual environmental variables was assessed, and significance was tested with Monte Carlo permutation tests (999 full model permutations, significance threshold $p=0.05$ ).

\section{Results}

Physicochemical data

Water temperature (Fig. 2A) did not differ among reaches. Significant differences were found among reaches for DRP (Fig. 2B), dissolved $\mathrm{O}_{2}$ (Fig. 2C), $\mathrm{NO}_{2}{ }^{-}$ (Fig. 2D), $\mathrm{NO}_{3}{ }^{-}$(Fig. 2E), $\mathrm{NH}_{4}{ }^{+}$(Fig. 2F), WC (Fig. 2G), and TP (Fig. 2H), but not for $\mathrm{SO}_{4}{ }^{2-}$ (Fig. 2I). N and $\mathrm{P}$ enrichment was highest in reach $\mathrm{C}$, whereas enrichment was lowest in reach $\mathrm{A}$ and reflected values frequently observed in the undisturbed coastal Mediterranean streams. Water velocity (mean $\pm \mathrm{SE}=34.1$ $\pm 15.3 \mathrm{~cm} / \mathrm{s}$ ) and surface area of stones (58.6 \pm $29.7 \mathrm{~cm}^{2}$ ) did not differ significantly among reaches (1way ANOVA, $p=0.4$ and 0.1 , respectively).

\section{Epilithon biomass and epilithic algae}

Chl $a$ and AFDM did not differ significantly among reaches (1-way ANOVA, $p=0.073$ and 0.318, respectively; Fig. 3A, B), partly because values were highly variable in reaches $B$ and $C$. Total algal cell density and total algal biovolume were significantly higher in reach $C\left(33,996\right.$ cells $/ \mathrm{cm}^{2}$ and $\left.3.54 \times 10^{8} \mu \mathrm{m}^{3} / \mathrm{cm}^{2}\right)$ than in reach A (1710 cells $/ \mathrm{cm}^{2}$ and $0.34 \times 10^{8} \mu \mathrm{m}^{3} /$ $\left.\mathrm{cm}^{2}\right)$, and they were intermediate in reach B $(6244$ cells $/ \mathrm{cm}^{2}$ and $0.38 \times 10^{8} \mu \mathrm{m}^{3} / \mathrm{cm}^{2}$ ) (1-way ANOVA, $p$ $<0.001$ for both variables; Fig. 3C, D).

Forty-nine algal taxa were recorded: 40 Diatomophyceae with 14, 39, and 35 taxa in reaches $\mathrm{A}, \mathrm{B}$, and $C$, respectively; 5 Chlorophyceae represented by 2 taxa in reach $A$, and 3 taxa in reaches $B$ and $C$; and 3 Cyanophyceae and 1 Rhodophyceae in reaches $B$ and $C$ (Appendix 1). Reach B had the highest algal taxonomic richness with 46 taxa; reaches $\mathrm{A}$ and $\mathrm{C}$ had 16 and 42 taxa, respectively.

Diatomophyceae had the highest cell densities among the 4 algal classes in each of the 3 reaches, and cells densities of Diatomophyceae, Chlorophyceae, and Rhodophyceae differed significantly among reaches (Table 1). Diatomophyceae cell densities were $18.85 \times$ greater in reach $\mathrm{C}$ than in reach $\mathrm{A}$. Rhodophyceae and Cyanophyceae cell densities were highest in reach $C$ and 0 in reach $A$. Chlorophyceae cell densities were highest in reach $\mathrm{C}$ and lowest in reach $\mathrm{B}$. Chlorophyceae had the greatest biovolumes among the 4 algal classes in each of the 3 reaches, and algal biovolumes of Diatomophyceae and Rhodophyceae differed significantly among reaches. Biovolumes of the 4 algal classes were highest in reach $\mathrm{C}$. 

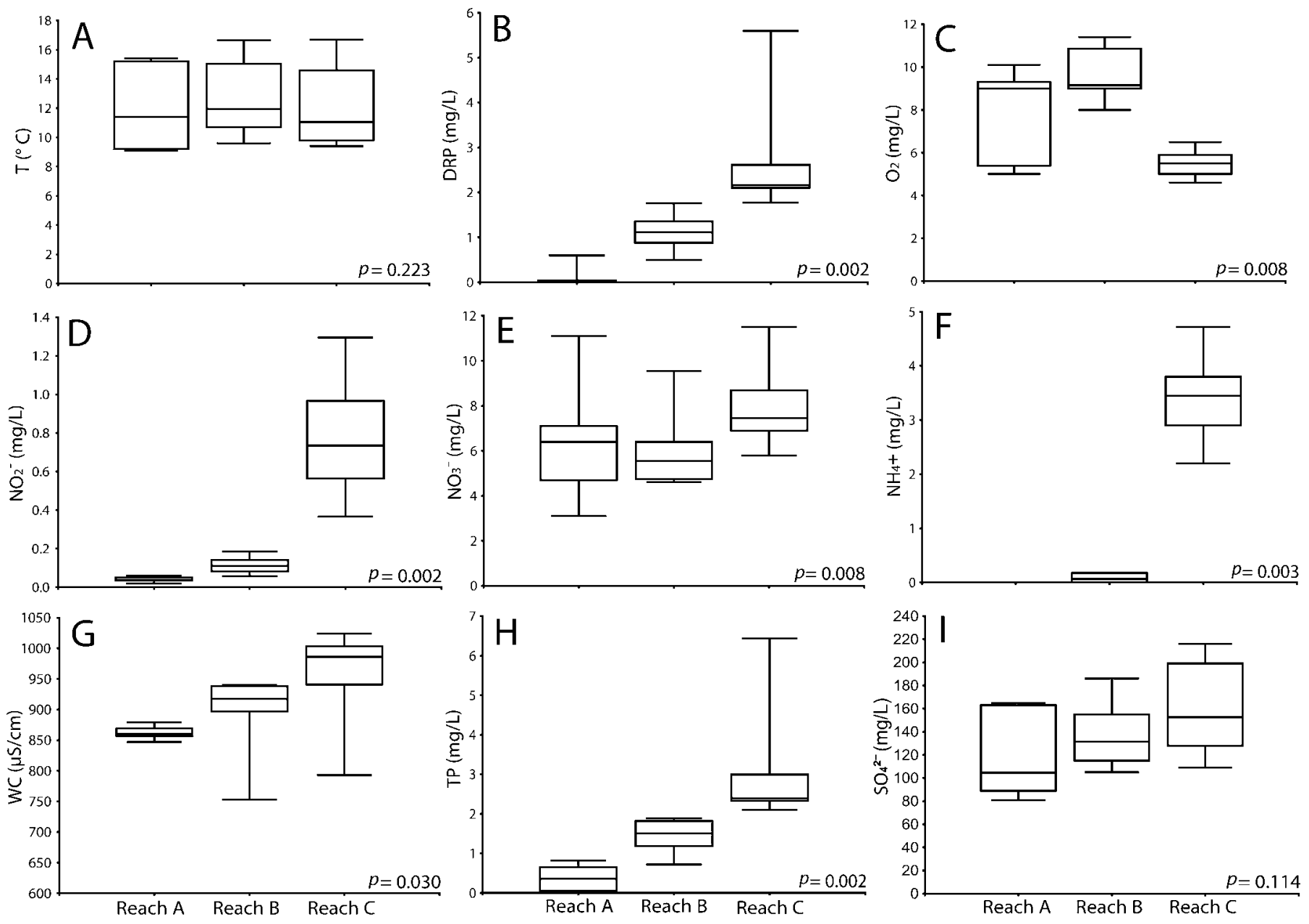

FIG. 2. Box-and-whisker plots of water temperature (T) (A), dissolved reactive $\mathrm{P}(\mathrm{DRP})$ (B), dissolved $\mathrm{O}_{2}(\mathrm{C}), \mathrm{NO}_{2}{ }^{-}(\mathrm{D}), \mathrm{NO}_{3}{ }^{-}(\mathrm{E})$, $\mathrm{NH}_{4}{ }^{+}(\mathrm{F})$, water conductivity (WC) (G), total P (TP) (H), and $\mathrm{SO}_{4}{ }^{2-}$ (I) in the 3 reaches of Arc stream. Whiskers indicate the range of the values observed (minimum-maximum), the line in the box is the median, and the ends of the rectangles represent the upper and lower quartiles. $p$-values refer to Friedman's tests for differences among reaches.

\section{Chironomid larval communities}

Altogether, 4149 chironomid larvae were collected from the 3 reaches. Orthocladiinae made up $98.9 \%$ of the community, whereas Diamesinae and Tanytarsini made up $0.8 \%$ and $0.3 \%$ of the community, respectively. Thirty-four chironomid taxa (31 Orthocladiinae, 2 Tanytarsini, and 1 Diamesinae) were identified (18 to species level and 16 to genus level).

Mean chironomid larval densities on the stones were 13, 57, and 176 larvae $/ \mathrm{dm}^{2}$ in reaches $\mathrm{A}, \mathrm{B}$, and C, respectively. In reach $\mathrm{A}$, Eukiefferiella claripennis, Orthocladius (Orthocladius) sp., and Thienemanniella majuscula were present in high densities $(>15 \%$ of the total abundance; Appendix 2). In reach B, the same taxa were dominant, but Orthocladius (Orthocladius) sp. and T. majuscula had lower and E. claripennis had higher relative abundances. In reach C, E. claripennis made up $83 \%$ of the community (mean density $=145$ larvae $/ \mathrm{dm}^{2}$ ), and relative abundances of the other taxa were $\leq 4 \%$.

The highest taxon richness was observed in reach $\mathrm{C}$ (23 taxa). Taxon richness was 15 and 17 in reaches $\mathrm{A}$ and B, respectively. Corynoneura species were present only in reach A, whereas Diamesa sp., Orthocladius ashei, Eukiefferiella devonica/ilkleyensis, and Tvetenia bavarica were present only in reach B, and Eukiefferiella coerulescens, Eukiefferiella minor, Paratrichocladius rufiventris, and Tvetenia discoloripes were present only in reach $\mathrm{C}$. The greatest numbers of species of Eukiefferiella and Cricotopus were found in reach C, and they contributed to the high taxonomic richness found at this station. Thirteen of the taxa encountered in our study were found only in reach $C$, the reach with the highest nutrient enrichment. 

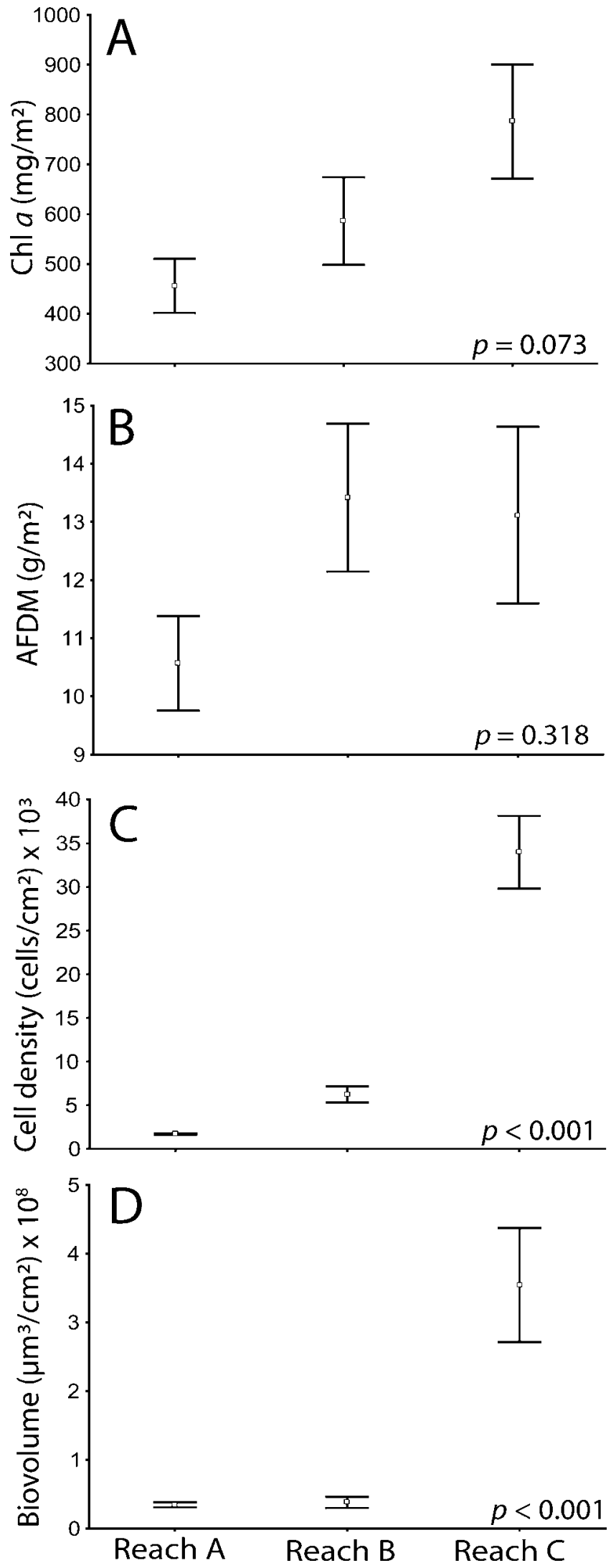

Distribution of chironomid taxa and epilithon

Correlations between chironomid densities and chl $a$ and AFDM were not significant (Kendall's $\tau$ correlation, $p=0.16$ and $p=0.93$, respectively, $n=81$; Fig. $4 \mathrm{~A}$, B), whereas correlations between chironomid densities with total cell densities and total algal biovolumes were highly significant ( $p<0.001$ for both; Fig. 4C, D). These patterns seemed to be driven mostly by samples from reach C (Fig. 4A-D). Chironomid densities were strongly correlated with algal cell densities $<4 \times 10^{6}$ cells $/ \mathrm{dm}^{2}(\tau=0.67, p<0.001, n=79)$, where chironomid density was always $\leq 350$ larvae $/ \mathrm{dm}^{2}$; just 2 samples had 492 and 506 larvae/ $\mathrm{dm}^{2}$.

At the genus level, Eukiefferiella density was most strongly correlated with biovolumes of Diatomophyceae and Rhodophyceae, but it also was significantly correlated with Cyanophyceae (Table 2). Cricotopus was significantly correlated with Diatomophyceae and Rhodophyceae, Thienemanniella was significantly correlated with Chlorophyceae, and Paratrichocladius was significantly correlated with Diatomophyceae and Cyanophyceae. At the species level, E. claripennis (85\% of the genus Eukiefferiella) density was strongly and significantly correlated with Rhodophyceae, Diatomophyceae, and Cyanophyceae. Cricotopus bicinctus was significantly correlated with Rhodophyceae and Diatomophyceae. Diamesa sp. was positively correlated with Cyanophyceae and negatively correlated with Chlorophyceae, whereas Micropsectra sp. was negatively correlated with Chlorophyceae and Rhodophyceae.

The first 2 axes of the CCA expressed $17.9 \%$ and $8.2 \%$ of the variance in the epilithic chironomid assemblage. The taxa-to-environment correlation coefficients along these 2 axes were $r=0.68$ and 0.49 , respectively. The first 2 axes explained $58.5 \%$ and $85.5 \%$, respectively, of the constrained variance (taxaenvironment relationship). The highly significant environmental variables were biovolumes of Chlorophyceae and Rhodophyceae $(p=0.019$ and 0.018, respectively). CCA identified biovolumes of Cyanophyceae, Chlorophyceae, and Diatomophyceae as the environmental variables most related to axis F1 and biovolume of Rhodophyceae as the environmental variable most strongly related to axis F2 (Fig. 5A).

FIG. 3. Mean ( $\pm 1 \mathrm{SE})$ chlorophyll $a$ (chl $a$ ) (A), ash-free dry mass (AFDM) (B), total algal cell density (C), and total algal biovolume (D) in the 3 reaches of Arc stream. The $p$ values refer to 1-way ANOVA tests for differences among reaches. 
TABLE 1. Mean, standard deviation (SD), and significance $(p)$ of 1-way ANOVA tests for differences in cell densities and biovolumes of the 4 algal classes among the 3 reaches (A, B, and C) of Arc stream.

\begin{tabular}{|c|c|c|c|c|c|c|c|c|c|c|c|c|}
\hline \multirow[b]{2}{*}{ Dependent variable } & \multicolumn{3}{|c|}{ Diatomophyceae } & \multicolumn{3}{|c|}{ Chlorophyceae } & \multicolumn{3}{|c|}{ Rhodophyceae } & \multicolumn{3}{|c|}{ Cyanophyceae } \\
\hline & $\mathrm{A}$ & B & C & A & B & C & A & B & C & A & B & $\mathrm{C}$ \\
\hline \multicolumn{13}{|l|}{$\begin{array}{l}\text { Cell density } \\
\quad\left(\text { cells } / \mathrm{cm}^{2} \times 10^{3}\right)\end{array}$} \\
\hline Mean & 2.78 & 14.66 & 52.40 & 2.53 & 1.53 & 20.1 & 0 & 2.09 & 29.12 & 0 & 0.45 & 6.57 \\
\hline SD & 0.87 & 10.71 & 56.43 & 0.53 & 0.63 & 27.7 & - & 2.92 & 19.87 & - & 0.54 & 6.71 \\
\hline$p$ & 0.015 & & & 0.006 & & & 0.008 & & & 0.113 & & \\
\hline \multicolumn{13}{|l|}{$\begin{array}{l}\text { Biovolume } \\
\quad\left(\mathrm{um}^{3} / \mathrm{cm}^{2} \times 10^{6}\right)\end{array}$} \\
\hline Mean & 1 & 7 & 39 & 31 & 28 & 318 & 0 & 1 & 23 & 0 & 0.02 & 0.56 \\
\hline SD & 0.30 & 5 & 42 & 14 & 28 & 448 & - & 2 & 15 & - & 0.02 & 0.66 \\
\hline$p$ & 0.006 & & & 0.449 & & & 0.008 & & & 0.294 & & \\
\hline
\end{tabular}

AFDM and chl $a$ had much weaker relationships to both axes than did algal biovolumes.

All samples from reach A were clustered at the negative end of axis 2 (Fig. 5B), and they were negatively correlated with the biovolume of Rhodophyceae (Fig. 5A). Densities of Corynoneura species, Rheocricotopus fuscipes, and T. majuscula were high in reach A samples (Fig. 5A, B). Samples from reach B plotted close to those of reach $\mathrm{A}$, but they were more variable (Fig. 5B), and they reflected the absence of Corynoneura species from reach B (Fig. 5A). Samples from reach $C$ were widely distributed along both axes (Fig. 5B). The position of these samples reflected the occurrence of taxa, such as C. bicinctus and Cricotopus tremulus, that were correlated with high biovolumes of Rhodophyceae or the occurrence of taxa, such as $P$. rufiventris, Paratrichocladius sp. 1., and Tvetenia calvescens, that were correlated with high biovolumes of Diatomophyceae, Cyanophyceae, and Chlorophyceae (Fig. 5A, B). Eukiefferiella claripennis was in a central position on the CCA plot, mainly because density of this species was strongly correlated with both Rhodophyceae and Diatomophyceae (Fig. 5A, B).

The CCA separated the chironomid taxa into 3 groups (Fig. 5A). Group 1 (determined mostly by samples from reach C) was associated with high biovolumes of Rhodophyceae and composed of all the Cricotopus species, Micropsectra sp., and T. discoloripes. Group 2 (also determined mostly by samples from reach C) was associated with high biovolumes of Cyanophyceae and composed of P. rufiventris, Paratrichocladius sp. 1, Tvetenia sp. 1, and T. calvescens. Group 3 (determined mostly by samples from reaches $A$ and B) was not explained by the variables used in the CCA and was composed of all the Corynoneura and Thienemaniella species, O. ashei, and Diamesa sp.

\section{Discussion}

Epilithon and chironomids under different degrees of enrichment

High concentrations of $\mathrm{N}$ and $\mathrm{P}$, primarily in reach $\mathrm{C}$, were associated with a 3 to $4 \times$ increase in total algal cell densities and total algal biovolume. Algal taxon richness increased in enriched reaches because of an increase of the number of Diatomophyceae taxa and the addition of Rhodophyceae and Cyanophyceae taxa. The chironomid assemblage showed similar changes; larval densities and taxon richness increased in response to nutrient enrichment. Only Corynoneura species were absent from the enriched reach, and species richness of taxa, such as Cricotopus and Eukiefferiella, was highest in reach $\mathrm{C}$.

The chironomid taxa found in our study were eliminated neither by water quality within the observed range of enrichment nor by the daily variation of dissolved $\mathrm{O}_{2}$ concentration (always $>4.5$ $\mathrm{mg} / \mathrm{L}$ ) encountered under such enrichment. Eukiefferiella claripennis was the dominant chironomid taxon in our study, especially in reach C $(7.3 \mathrm{~km}$ downstream from the effluent). Eukiefferiella claripennis has been reported as a taxon highly tolerant of eutrophication (Zavrel 1939) and inputs of sewage effluent (Davies and Hawkes 1981). Cricotopus bicinctus, also abundant in the enriched reach, has been reported in great numbers under high enrichment caused by organic pollution (Davies and Hawkes 1981, Laville and Viaud-Chauvet 1985). Thus, high abundances of these 2 taxa strongly indicate stream enrichment.

In our study, E. claripennis was more abundant than C. bicinctus. Davies and Hawkes (1981) and Singh and Harrison (1984) reported that E. claripennis was multivoltine $(\geq 3$ generations/y) with generations occurring in March and May. The higher density of 

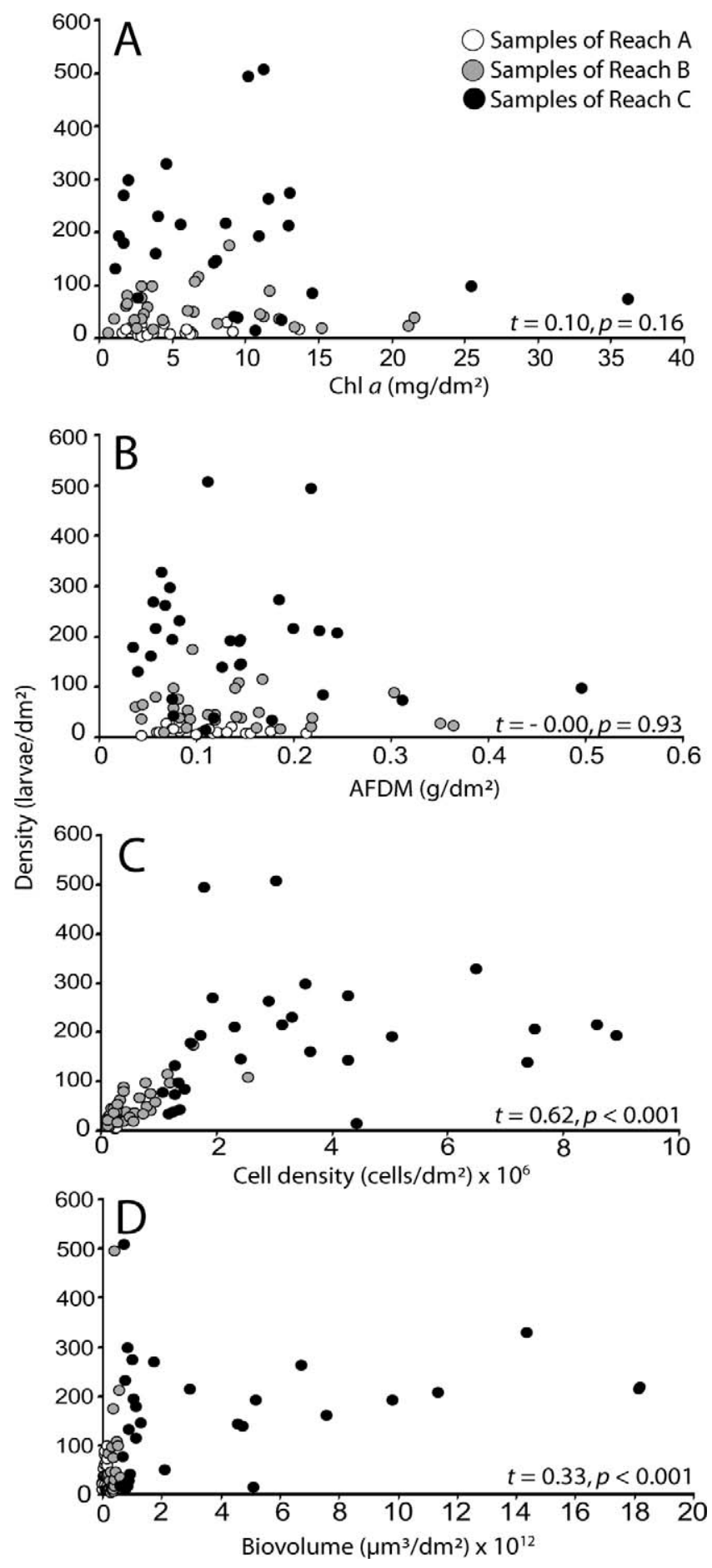

FIG. 4. Scatterplots showing the relationships between chironomid larval densities and chlorophyll $a(\mathrm{chl} a)$ (A), ashfree dry mass (AFDM) (B), total algal cell density (C), and total algal biovolume (D) in the 3 reaches of Arc stream. Kendall's $\tau$ coefficients of rank correlations $(t)$ are based on samples from all 3 reaches. All samples are shown, but some points overlap, especially those for reach A.
E. claripennis than C. bicinctus can be explained by its restriction to cool waters $\left(<15^{\circ} \mathrm{C}\right)$ (e.g., Lencioni and Rossaro 2005). Emergent $C$. bicinctus have a temperature preference of $18.9^{\circ} \mathrm{C}$ (Rossaro 1991). However, in Mediterranean streams, water levels drop drastically as water temperature reaches $20^{\circ} \mathrm{C}$ (July 2004 for reach C). Rheophilic taxa, such as C. bicinctus, are more affected by the loss of riffle area than is E. claripennis (AM, personal observation). Thus, taxa, such as $C$. bicinctus, with preferences for high temperatures are less important in Mediterranean food webs than they are under different climate conditions.

\section{Algal vs nonalgal epilithon}

AFDM did not differ among reaches; therefore, the higher densities of rheophilic chironomids in reach $C$ than in reach A cannot be explained by this variable. The fine organic deposit (i.e., bacteria and detritus), which makes up much of AFDM, does not seem attractive to larvae and does not seem to have a direct effect on the distribution of the epilithic chironomid assemblage. Food quality of algae is often much higher than that of detritus (Cummins and Klug 1979), and algae is a more nutritious food source than detritus for invertebrates. Algal biomass ( $\mathrm{chl} a$ ) tended to be higher in reach $\mathrm{C}$ than in reach $\mathrm{A}$, but it was not significantly different among reaches. Chl $a$ concentrations differ among classes of algae (Dixon and Irvine 1977), and chl $a$ does not always reflect algal cell densities because different algal taxa do not have the same number of chloroplasts. Also, chl a concentration is low in budding and dying algae (Bonin and Travers 1992), even though these cells are available as food resources.

Our results emphasize the important influence of algal cell densities and biovolumes on chironomid larval distribution. Nutrient enrichment corresponded to higher algal cell densities and biovolumes, which corresponded with an increase in chironomid larval densities. Algal cell density and biovolume were correlated, but algal biovolume might be the measure that is most directly related to energy value of algae to herbivores. In our study, as in other studies (Cattaneo 1987, DeNicola et al. 2006), the increase in total algal biovolume observed with nutrient enrichment reflected the increase in algal cell densities, and it was related to an increase in algal taxa with larger cell sizes (e.g., Chlorophyceae and Rhodophyceae vs Diatomophyceae).

Eukiefferiella claripennis and C. bicinctus were the chironomid taxa most strongly correlated with algal biovolume. These chironomids are fixed-tube scrapers that feed on available organic matter (i.e., algal cells) on the stone surface, and the high correlations suggest 
TABLE 2. Kendall's $\tau$ correlation coefficients of selected chironomid taxa with total biovolume of each algal class. Coefficients of taxa represented by $<10$ larvae are not included. ${ }^{*}=$ statistically significant based on Bonferroni-adjusted threshold of significance. $n=$ number of larvae encountered.

\begin{tabular}{|c|c|c|c|c|c|}
\hline Taxon & $n$ & Diatomophyceae & Chlorophyceae & Rhodophyceae & Cyanophyceae \\
\hline \multicolumn{6}{|l|}{ Orthocladiinae } \\
\hline Cricotopus & 79 & $0.326^{*}$ & 0.085 & $0.470^{*}$ & 0.074 \\
\hline Cricotopus (Cricotopus) spp. & 22 & 0.168 & 0.025 & $0.234^{*}$ & 0.063 \\
\hline Eukiefferiella & 3379 & $0.568^{*}$ & 0.129 & $0.655^{*}$ & $0.315^{*}$ \\
\hline Eukiefferiella claripennis (Lundbeck, 1898) & 2860 & $0.534^{*}$ & 0.088 & $0.647^{*}$ & $0.297^{*}$ \\
\hline Orthocladius (Orthocladius) spp. & 93 & -0.185 & -0.065 & $-0.200^{*}$ & 0.098 \\
\hline Paratrichocladius & 37 & $0.251^{*}$ & 0.175 & 0.117 & $0.242^{*}$ \\
\hline Paratrichocladius spp. & 28 & $0.239^{*}$ & 0.163 & 0.113 & $0.226^{*}$ \\
\hline Thienemanniella & 198 & 0.037 & $0.263^{*}$ & 0.021 & $0.040^{*}$ \\
\hline \multicolumn{6}{|l|}{ Tanytarsini } \\
\hline Micropsectra sp. & 13 & 0.093 & $-0.213^{*}$ & $-0.228^{*}$ & -0.074 \\
\hline
\end{tabular}

that the foraging behavior of these 2 taxa is closely related to the algal cell densities.

\section{Algal assemblage structure and chironomids}

The correlations between chironomid taxa and algal biovolumes and the CCA results indicate that chironomid taxa might have preferences for certain algae types (classes in our study) available on the upper surface of the stones. Rhodophyceae have not been reported as a food source for chironomids, and the correlation between chironomid density and Rhodophyceae is a novel finding, although filamentous cells of Audouinella sp. have been observed in guts of $E$. claripennis and C. bicinctus (AM, personal observation). Audouinella sp. seems to play a direct (ingestion of filamentous cells) or indirect (supporting epiphytic Diatomophyceae or gathering fine particulate organic matter) role as a food source, and gut content analysis will clarify whether Audouinella sp. cells are grazed electively. Chironomid larvae and filamentous algae can have complex interactions. For example, Pseudochironomus richardsoni had different interactions with the filamentous alga Cladophora depending on the larval instar and the development rate of the filaments (Power 1991). Hence, additional investigations are necessary to elucidate the trophic interaction between C. bicinctus and E. claripennis and Audouinella sp.

Cricotopus bicinctus graze on epiphytic diatoms and often are associated with macrophyte stems (Drake 1983, Tokeshi and Pinder 1986) or filamentous algae (Mason and Bryant 1975). High correlations were found between $C$. bicinctus density and biovolumes of classes of algae (Chlorophyceae and Diatomophyceae) previously documented as food sources for chironomid larvae (Silver Botts and Cowell 1992, Armitage et al. 1995). These algal classes are digested quickly (Marker et al. 1986). Cyanophyceae have been reported as unimportant as a food source for chironomid larvae (Davies 1975, Johnson et al. 1989), but we found a significant correlation between density of Diamesa sp. and Cyanophyceae biovolume, a result that concurs with the observations by Kawecka et al. (1978) that Diamesa spp. fed mainly on Cyanophyceae in a glacial stream.

Other studies have explained the distribution of chironomid larvae on the basis of substratum type (e.g., Wiley 1981, Pinder 1986). However, our study identified differences among chironomid assemblages in the same physical conditions (stone surface area, water velocity, and water temperature) but with different epilithon quality (algae vs nonalgal organic matter and different classes within the algal assemblage). Periphyton quality determined the patch preference of the grazing chironomid Paratanytarsus dubius in laboratory microcosms (Gresens and Lowe 1994). In our descriptive field study, epilithic algal assemblage structure seems to have had a major influence on the epilithic chironomid assemblage.

The bottom-up effect of nutrient enrichment on the epilithic algal assemblage in riffles seems to be an important factor structuring the rheoplilic chironomid assemblage in our study stream. Nutrient enrichment increases algal abundance, and the effect of increased algal abundance on chironomid density could have been strengthened by differences among reaches in turnover time, which can lead to 20-fold differences in 


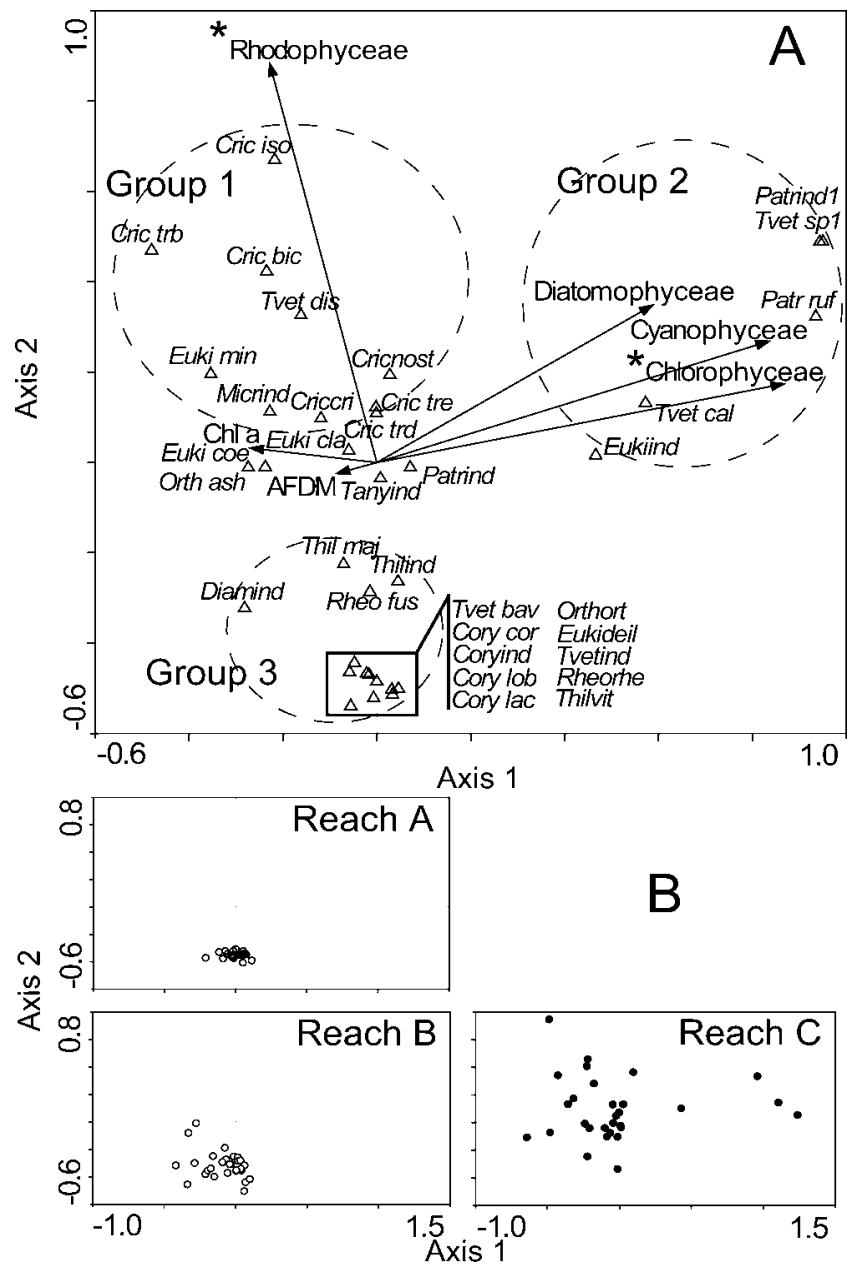

FIG. 5. Species (A) and sample (B) canonical correlation analysis ordination diagrams. In the species ordination, arrows indicate direction and strength of the correlation between the explanatory variables and the axes (* indicates a significant relationship). Circles delimit groups of chironomid taxa. In the sample ordination, samples for each reach are plotted separately to reduce overlapping of points and to facilitate interpretation. Chlorophyll $a(\mathrm{chl} a)$, ash-free dry mass (AFDM), algal class names indicate biovolumes for each class. Chironomid taxon codes are given in Appendix 2.

the ability of benthic algae to support grazer biomass (Summer and McIntire 1982). Other invertebrates can affect chironomid assemblages by predation or food competition in some systems, but under the high enrichment levels observed in reach $C$ where nontolerant invertebrates are absent, chironomids are probably the major energy link between autotrophic producers and secondary consumers. Chironomid larvae also can affect the epilithic algal assemblage by grazing on preferred algal taxa. Further investigations that take into account ingestion rates and selectivity of larvae present in great numbers (i.e., $E$. claripennis and C. bicinctus) are required to elucidate the trophic relationship between these taxa and the community structure of epilithic algae found in our study.

\section{Acknowledgements}

Grateful acknowledgment is expressed to Stephen J. Brooks for his welcome at the Natural History Museum of London in March 2005. He allowed access to the Chironomidae collection and gave helpful recommendations for head-capsule identification. Comments from Dean DeNicola, Pamela Silver, and 2 anonymous referees greatly improved an earlier version of our manuscript. This project was supported financially by the Conseil Général des Bouches-duRhône: Service de l'Eau et des Milieux Aquatiques, the Syndicat d'Aménagement du Bassin de l'Arc, and the Agence de l'Eau Rhône-Méditerranée-Corse.

\section{Literature Cited}

Ali, A., J. Frouz, AND R. J. LobinSKe. 2002. Spatio-temporal effects of selected physico-chemical variables of water, algae, and sediment chemistry on the larval community of nuisance Chironomidae (Diptera) in a natural and a man-made lake in central Florida. Hydrobiologia 470: 181-193.

Armitage, P. D., AND J. H. Blackburn. 1985. Chironomidae in a Pennine stream system receiving mine drainage and organic enrichment. Hydrobiologia 121:165-172.

Armitage, P., P. S. Cranston, and L. C. V. Pinder. 1995. The Chironomidae: the biology and ecology of non-biting midges. Chapman and Hall, London, UK.

BenKe, A. C. 1998. Production dynamics of riverine chironomids: extremely high biomass turnover rates of primary consumers. Ecology 79:899-910.

BerG, M. B. 1995. Larval food and feeding behaviour. Pages 136-168 in P. Armitage, P. S. Cranston, and L. C. V. Pinder (editors). The Chironomidae: biology and ecology of non-biting midges. Chapman and Hall, London, UK.

Bode, R. W. 1983 Larvae of North American Eukiefferiella and Tvetenia (Diptera: Chironomidae). New York State Museum, Albany, New York.

Bonada, N., M. Rieradevall, N. Prat, and V. H. Resh. 2006. Benthic macroinvertebrate assemblages and macrohabitat connectivity in Mediterranean-climate streams of northern California. Journal of the North American Benthological Society 25:32-43.

Bonin, D. J., AND M. TRAVERS. 1992. Examen critique des méthodes d'estimation de la biomasse et de l'activité des microorganismes dans les systèmes aquatiques. Marine Life 2:1-29.

Bourrelly, P. 1966. Les algues d'eau douce. Initiation à la systématique. 1: les algues vertes. Boubée, Paris, France.

Bourrelly, P. 1968. Les algues d'eau douce. Initiation à la systématique. 2: les algues jaunes et brunes. Boubée, Paris, France. 
Bourrelly, P. 1970. Les algues d'eau douce. Initiation à la systématique. 3: les algues bleues et rouges, les Euglèniens, Peridiniens et Cryptomonadines. Boubée, Paris, France.

Calle-Martinez, D., And J. J. Casas. 2006. Chironomid species, stream classification, and water-quality assessment: the case of 2 Iberian Mediterranean mountain regions. Journal of the North American Benthological Society 25:465-476.

Cattaneo, A. 1987. Periphyton in lakes of different trophy. Canadian Journal of Fisheries and Aquatic Sciences 44: 296-303.

Chaloner, D. T., AND R. S. Wotton. 1996. Substratum preferences by larvae of three species of midge (Diptera: Chironomidae). Hydrobiologia 339:93-99.

Cummins, K. W., and M. J. KLug. 1979. Feeding ecology of stream invertebrates. Annual Review of Ecology and Systematics 10:147-172.

DAVIES, I. J. 1975. Selective feeding in some arctic Chironomidae. Verhandlungen der Internationalen Vereinigung für theoretische und angewandte Limnologie 19:31493154.

DAVIES, L. J., AND H. A. HAWKes. 1981. Some effects of organic pollution on the distribution and seasonal incidence of Chironomidae in riffles in the River Cole. Freshwater Biology 11:549-559.

DeNicola, D. M., E. De Eyto, A. Wemaere, And K. Ivrine. 2006. Periphyton response to nutrient addition in 3 lakes of different benthic productivity. Journal of the North American Benthological Society 25:616-631.

Dixon, P. S., And L. M. IRvine. 1977. Seaweeds of the British Isles. British Museum (Natural History), London, UK.

DraKe, C. M. 1982. Seasonal dynamics of Chironomidae (Diptera) on the bulrush Schoenoplectus lacustris in a chalk stream. Freshwater Biology 12:225-240.

DRAKE, C. M. 1983. Spatial distribution of chironomid larvae (Diptera) on leaves of the bulrush in a chalk stream. Journal of Animal Ecology 52:421-437.

FRANQUET, E. 1999. Chironomid assemblage of a LowerRhône dike field: relationships between substratum and biodiversity. Hydrobiologia 397:121-131.

GoldFinch, A. C., AND K. R. CARMAn. 2000. Chironomid grazing on benthic microalgae in a Louisiana salt marsh. Estuaries 23:536-547.

Gresens, S. E. 1995. Grazer diversity, competition and the response of the periphyton community. Oikos 73:336346.

Gresens, S. E., AND R. L. Lowe. 1994. Periphyton patch preference in grazing chironomid larvae. Journal of the North American Benthological Society 13:89-99.

Holm, S. 1979. A simple sequentially rejective multiple test procedure. Scandinavian Journal of Statistics 6:65-70.

JEFFREY, S. W., AND G. F. HuMPHREY. 1975. New spectrophotometric equations for determining chlorophylls a, b, $c_{1}$ and $c_{2}$ in higher plants, algae and natural plankton. Biochemie und Physiologie der Pflanzen 10:191-194.

Johnson, R. K., B. BoströM, AND W. VAN DER Bund. 1989. Interactions between Chironomus plumosus (L.) and the microbial community in surficial sediments of a shallow, eutrophic lake. Limnology and Oceanography 34:9921003.

Kawecka, B., A. Kownacki, and M. Kownacka. 1978. Food relations between algae and bottom fauna communities in glacial streams. Verhandlungen der Internationalen Vereinigung für theoretische und angewandte Limnologie 20:1527-1530.

Klink, A. G., AND H. K. M. Moller Pillot. 2002. Chironomidae larvae: key to higher taxa and species of the lowlands of northwestern Europe. ETI Information Services, Amsterdam, The Netherlands. (Available from: http:/ / www.eti.uva.nl/)

Krammer, K., and H. Lange-Bertalot. 1986. Süßwasserflora von Mitteleuropa. Baccillariophyceae. 1. Teil: Naviculaceae. Gustav Fischer Verlag, Stuttgart, Germany.

Krammer, K., and H. Lange-Bertalot. 1988. Süßwasserflora von Mitteleuropa. Baccillariophyceae 2. Teil: Bacillariaceae, Epithemiaceae, Surirellaceae. Gustav Fischer Verlag, Stuttgart, Germany.

Krammer, K., AND H. LANGE-Bertalot. 1991a. Süßwasserflora von Mitteleuropa. Baccillariophyceae, 3. Teil: Centrales, Fragilariaceae, Eunotiaceae. Gustav Fischer Verlag, Stuttgart, Germany.

Krammer, K., and H. Lange-Bertalot. 1991b. Süßwasserflora von Mitteleuropa. Baccillariophyceae 4. Teil: Achnanthaceae. Gustav Fischer Verlag, Stuttgart, Germany.

LANGTON, P. H. (EDITOR). 1991. A key to pupal exuviae of West Palaearctic Chironomidae. Huntingdon, Cambridgeshire, UK.

Laville, H., AND M. Viaud-Chauvet. 1985. Etude comparée de la structure des peuplements de Chironomidés dans cinq rivières du Massif Central: relation entre cette structure et la qualité des eaux. Verhandlungen der Internationalen Vereinigung für theoretische und angewandte Limnologie 22:2261-2269.

Lencioni, V., AND B. Rossaro. 2005. Microdistribution of chironomids (Diptera: Chironomidae) in Alpine streams: an autoecological perspective. Hydrobiologia 533:61-76.

Marker, A. F. H., R. T. Clarke, AND J. A. Rother. 1986. Changes in epilithic populations of diatoms, grazed by chironomid larvae, in an artificial recirculating stream. Pages 143-149 in F. E. Round (editor). Proceedings of the $9^{\text {th }}$ Diatom Symposium. Biopress, Bristol, UK.

Mason, C. F., AND R. J. BRYANT. 1975. Periphyton production and grazing by chironomids in Alderfen Broad, Norfolk. Freshwater Biology 5:271-277.

Mattingly, R. L., K. W. Cummins, and R. H. King. 1981. The influence of substrate organic content on the growth of stream chironomids. Hydrobiologia 77:161-165.

McLachlan, A. J., A. Brennan, AND R. S. Wotton. 1978. Particle size and chironomid (Diptera) food in an upland river. Oikos 31:247-252.

Millerioux, G. 1975. Comparaison des méthodes spectrophotométrique pour calculer des pigments phytoplanctoniques. Annales de la Station Biologique de Besse-enChandesse 9:57-59.

PInder, L. C. V. 1986. Biology of freshwater Chironomidae. Annual Review of Entomology 31:1-23.

POWER, M. E. 1991. Shifts in the effect of tuft-weaving midges 
on filamentous algae. American Midland Naturalist 125: 275-285.

RAE, J. G. 2004. The colonization response of lotic chironomid larvae to substrate size and heterogeneity. Hydrobiologia 524:115-124.

Rodier, J. 1984. L'analyse de l'eau: eaux naturelles, eaux résiduaires et eaux de mer. Dumond, Paris, France.

Rossaro, B. 1991. Chironomids and water temperature. Aquatic Insects 13:87-98.

Ruse, L. P., AND R. S. Wilson. 1984. The monitoring of river water quality within the Great Ouse basin using chironomid exuvial analysis technique. Water Pollution Control 83:116-135.

Schmid, P. E. 1993. A key to the larval Chironomidae and their instars from the Austrian Danube region streams and rivers. Federal Institute for Water Quality, Vienna, Austria.

Schnell, O. A., M. Rieradevall, I. Ganados, and O. Hanssen. 1999. A chironomid taxa coding system for use in ecological and palaeoecological databases. Report No. 3710-97. MOLAR Project Manual. Norwegian Institute for Water Research, Bergen, Norway.

SiLver BotTs, P. 1993. The impact of small chironomid grazers on epiphytic algal abundance and dispersion. Freshwater Biology 30:25-33.

Silver BotTs, P., AND B. C. Cowell. 1992. Feeding electivity of two epiphytic Chironomidae in a subtropical lake. Oecologia (Berlin) 89:331-337.

Singh, M. P., AND A. D. HARRISON. 1984. The chironomid community (Diptera: Chironomidae) in a Southern Ontario stream and the annual emergence patterns of common species. Archiv für Hydrobiologie 99:221-253.

Summer, W. T., AND C. D. McInTIRE. 1982. Grazer-periphyton interactions in laboratory streams. Archiv für Hydrobiologie 93:135-157.
ToKeshi, M. 1986. Population dynamics, life histories and species richness in an epiphytic Chironomidae community. Freshwater Biology 16:431-441.

TOKESHI, M., AND L. C. V. PINDER. 1986. Dispersion of epiphytic chironomid larvae and the probability of random colonization. Internationale Revue der gesamten Hydrobiologie 71:613-620.

UTERMÖHL, H. 1958. Zur vervollkommung der quantitativen phytoplankton methodik. Mitteilung der Internationalen Vereinigung für Limnologie 9:1-39.

Vos, J. H., M. Teunissien, J. F. Postman, and F. P. van den Ende. 2002. Particle size effect on preferential settlement and growth rate of detritivorous chironomid larvae as influenced by food level. Archiv für Hydrobiologie 154: 103-119.

WARD, G. M., AND K. W. Cummins. 1979. Effects of food quality on growth of a stream detritivore, Paratendipes albimanus (Meigen) (Diptera: Chironomidae). Ecology 60:57-64.

Wiederholm, T. (EDITOR). 1983. Chironomidae of the holarctic region. Keys and diagnoses, Part 1. Larvae. Entomologica Scandinavica Supplement 19:1-457.

WILEY, M. J. 1981. Interacting influences of density and reference on the emigration rates of some lotic chironomid larvae (Diptera: Chironomidae). Ecology 62:426438.

WiLSON, R. S. 1994. Monitoring the effect of sewage effluent on the Oxford Canal using chironomid pupal exuviae. Journal of the Institution of Water and Environmental Management 8:171-182.

Zavrel, J. 1939. Chironomidarum larvae et nymphae II. (Genus Eukiefferiella Th.). Acta Societatis Scientiarum Naturalium Moraviacae 6:1-29. 
APPENDIX 1. Mean relative abundances (\%) of algal taxa collected from 3 reaches of the Arc stream. $n=6$ sampling periods.

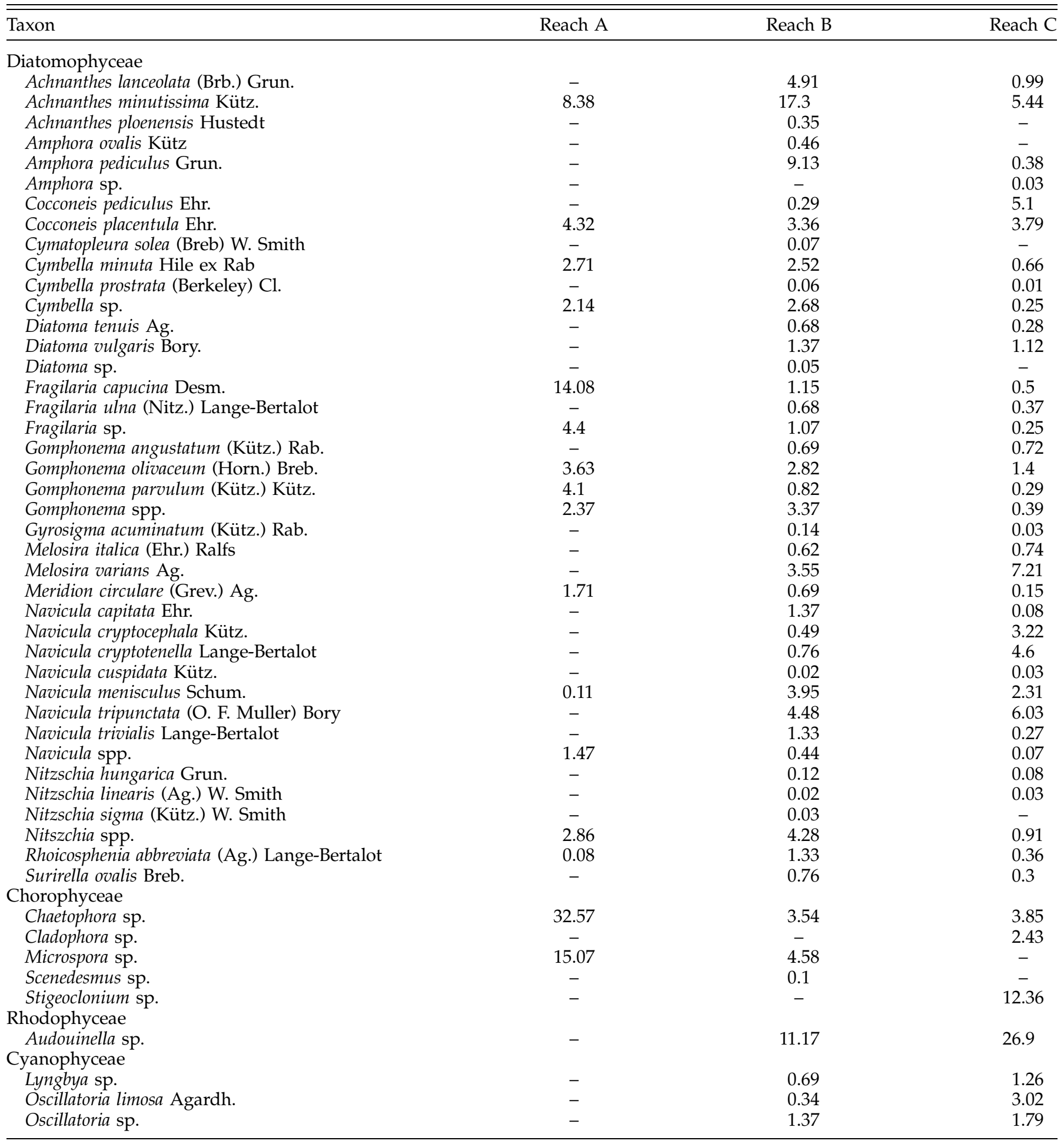


APPENDIX 2. Mean relative abundances (\%) of Chironomidae collected from 3 reaches of the Arc stream. $n=6$ sampling periods. Taxon codes are used in Fig. 5.

\begin{tabular}{|c|c|c|c|c|}
\hline Taxon & Taxon code & Reach A & Reach B & Reach C \\
\hline \multicolumn{5}{|l|}{ Orthocladiinae } \\
\hline Corynoneura coronata (Edwards, 1924) & Cory cor & 1.52 & - & - \\
\hline Corynoneura lacustris (Edwards, 1924) & Cory lac & 1.01 & - & - \\
\hline Corynoneura lobata (Edwards, 1924) & Cory lob & 1.52 & - & - \\
\hline Corynoneura spp. & Coryind & 0.5 & - & - \\
\hline Cricotopus (Cricotopus) bicinctus (Meigen, 1818) & Cric bic & - & 0.31 & 1.57 \\
\hline Cricotopus (Cricotopus) trifascia (Edwards, 1929) & Cric trb & - & - & 0.06 \\
\hline Cricotopus (Isocladius) trifasciatus (Meigen, 1813) & Cric trd & - & - & 0.03 \\
\hline Cricotopus (Cricotopus) tremulus (Linnaeus, 1758) & Cric tre & - & - & 0.07 \\
\hline Cricotopus (Cricotopus) spp. & Criccri & 0.5 & 1.26 & 0.37 \\
\hline Cricotopus (Isocladius) spp. & Cric iso & - & - & 0.07 \\
\hline Cricotopus (Nostococladius) spp. & Cricnost & - & - & 0.02 \\
\hline Eukiefferiella claripennis (Lundbeck, 1898) & Euki cla & 44.7 & 63.4 & 82.8 \\
\hline Eukiefferiella coerulescens (kieffer, 1926) & Euki coe & - & - & 0.17 \\
\hline Eukiefferiella minor (Edwards, 1929) & Euki min & - & - & 0.03 \\
\hline Eukiefferiella devonica/ilkleyensis & Eukideil & - & 0.1 & - \\
\hline Eukiefferiella spp. & Eukiind & 2.03 & 6.92 & 9.77 \\
\hline Orthocladius (Euorthocladius) ashei (Soponis, 1990) & Orth ash & - & 0.21 & - \\
\hline Orthocladius (Orthocladius) spp. & Orthort & 22.3 & 13 & 0.2 \\
\hline Paratrichocladius rufiventris (Meigen, 1830) & Patr ruf & - & - & 0.27 \\
\hline Paratrichocladius spp. & Patrind & 1.02 & 1.57 & 0.5 \\
\hline Paratrichocladius sp. 1 & Patrind1 & - & - & 0.03 \\
\hline Rhoocricotopus (Rheocricotopus) fuscipes (Kieffer, 1909) & Rheo fus & 2.54 & - & 0.07 \\
\hline Rheocricotopus (Rheocricotopus) spp. & Rheorhe & 0.51 & 0.1 & - \\
\hline Thienemanniella majuscula (Edwards, 1924) & Thil maj & 17.8 & 7.65 & 3.2 \\
\hline Thienemanniella spp. & Thilind & 2.45 & 0.77 & 0.11 \\
\hline Thienemanniella vittata (Edwards, 1924) & Thilvit & 0.51 & 0.1 & - \\
\hline Tvetenia bavarica (Goetghebuer, 1934) & Tvet bav & - & 0.52 & - \\
\hline Tvetenia calvescens (Edwards, 1929) & Tvet cal & - & 0.1 & 0.03 \\
\hline Tvetenia discoloripes (Goetghebuer, 1936) & Tvet dis & - & - & 0.07 \\
\hline Tvetenia sp. 1 & Tvet $\mathrm{sp} 1$ & - & - & 0.03 \\
\hline Tvetenia spp. & Tvetind & 0.57 & 0.09 & - \\
\hline \multicolumn{5}{|l|}{ Tanytarsini } \\
\hline Micropsectra sp. & Micrind & - & 0.1 & 0.4 \\
\hline Tanytarsus sp. & Tanyind & - & - & 0.03 \\
\hline \multicolumn{5}{|l|}{ Diamesinae } \\
\hline Diamesa sp. & Diamind & - & 3.35 & - \\
\hline Total no. of chironomid larvae & & 197 & 954 & 2998 \\
\hline
\end{tabular}

